\title{
Exemplaria
}

Medieval, Early Modern, Theory

\section{Homotopia, or, Reading Sagas on an Industrial Estate}

\section{Richard Cole}

To cite this article: Richard Cole (2018) Homotopia, or, Reading Sagas on an Industrial Estate, Exemplaria, 30:2, 105-128, DOI: 10.1080/10412573.2018.1453647

To link to this article: https://doi.org/10.1080/10412573.2018.1453647

曲 Published online: 25 May 2018.

Submit your article to this journal ${ }^{\pi}$

Q View related articles $\widetilde{ }$

View Crossmark data $\widetilde{ }$ 


\title{
Homotopia, or, Reading Sagas on an Industrial Estate
}

\author{
Richard Cole \\ University College London
}

\begin{abstract}
What are the psychological forces that imbue certain spaces with emotional power? Michel Foucault described one such space as "heterotopia." Heterotopias are places of extreme color and diversity, where the magical coming-together of usually contradictory forces exerted profound influence on people's emotions. This article presents spaces in Old Norse literature where it is not difference and strangeness that have dramatic impact, but rather sameness and familiarity. The term "homotopia" is proposed to describe such spaces. Scenes depicting two particular farmsteads from the sagas, Helgafell and Hlíðarendi, are considered as homotopias. Moreover, with reference to Karl Marx's theory of labor alienation, it is argued that homotopias have the potential to serve as political propaganda, convincing workers that their workplaces are not sites of exploitation, but are instead objects of aesthetic enjoyment. With this political purpose in mind, literary artifacts from the Old Norse-speaking world are integrated into an intellectual genealogy arriving at the present day. In closing it is therefore suggested that some of the homotopias of the Íslendingasögur provide parallels with the homotopian industrial estates and strip malls of late capitalism.
\end{abstract}

\section{KEYWORDS}

Alienation; Eyrbyggja saga; heterotopia; Iceland; Landnámabók; landscape; Njáls saga

\section{Introduction: on heterotopias}

On March 14, 1967 the French post-structuralist Michel Foucault delivered a lecture to the Cercle détudes architecturales in Paris. There, he explained how he had identified a sort of space, which he called "the heterotopia" (l'hétérotopie). ${ }^{1}$ Foucault's definition, later given in print, is elaborate, but it can essentially be condensed thus: heterotopias are spaces where difference is concentrated so as to arouse strong, transformative feelings (wonder, desire, awe, timelessness, etc.). One must quickly explain what is meant here by "difference," signi-


(Liddell and Scott 1996, 702). Foucault intended this difference to be interpreted broadly beginning with binary oppositions (e.g., life versus death; fire versus water; chastity versus lust) but potentially expandable to include less concrete notions of diversity (e.g., Christian versus Muslim; Spanish versus Aztec). He supplied specific examples of spaces that he considered to be heterotopian. Foucault began with the spooky stillness of the cemetery, a 
space that accommodates both death and life, an outpost of the dead often located at the heart of cities, which are intrinsically domains of the living $(1986,25)$. So too was there the Finnish sauna, a space where the heat of fire meets the cold of water, where men and women are cramped together nude yet the purpose is purificatory rather than sexual, where time often feels like it is moving at a different rate within the sauna than without (1986, 26). ${ }^{2}$ He proposed the honeymoon suite as a comparable example - a space constructed to accommodate the supposed virginity and wholesomeness of the bride with the carnality of consummation (1986, 24-25). Maritime vessels also came in for heterotopian analysis, being disposable spaces where diverse individuals, who might otherwise never associate, are temporarily forced into a sealed microcosm of the outside world: a floating simulacrum of terrestrial life traversing the waves $(1986,27)$.

The concept was typically Foucauldian: a celebration of diversity, of strangeness, of transgression, of what is weird and wonderful and, occasionally, a little kinky. Broadly speaking, the identification of the heterotopia was therefore conversant with general interests in post-structuralist cultural criticism at large. Alterity is usually considered more interesting than familiarity because difference is more compelling than sameness: stories of non-conformists, of phenomena beyond most people's everyday experience, of ways of living which challenge social norms, have an undeniable appeal. In the same vein that Judith Butler draws our attention to bodies that refuse to fall into familiar gender roles, or Edward Said focused on the imposition of unfamiliarity and exoticism onto the Orient, Foucault offered a geographical critique of dramatically unfamiliar spaces.

The intellectual preoccupation with difference is both understandable and laudable. It has produced scholarship that empowers people who live on the margins of society by paying serious attention to their experiences. However, the natural appeal of difference does not preclude the fact that sameness also has an ability to invoke stirring emotions. Foucault does not appear to have considered this possibility in his theory of space. He sketched out heterotopias in opposition to what he called "the space of emplacement" (espace de localisation). Unlike heterotopias, in this variety of space things were arranged in their natural order, without internal contradiction. Here was the quotidian, humdrum space of daily life, where people went about their business untroubled by any strangeness in their environment: "where things found their natural ground and stability" (1986, 22). Foucault even went so far as to claim that the space of emplacement was "what could very roughly be called medieval space: the space of emplacement" $(1986,22)$. However, medievalists have identified plenty of instances where medieval culture created Foucauldian heterotopias. ${ }^{3}$ Such findings are quite in opposition to Foucault's questionable claim that the Middle Ages could only produce spaces of emplacement until Galileo supposedly shattered European cosmology in c. 1610 (1986, 22-23).

When Foucault defined the heterotopia against the space of emplacement, he did not provide for the possibility that the heterotopia could have a diametric opposite. There is no doubt that the space of emplacement contrasts with the heterotopia in terms of its emotive power. The sense of difference in a heterotopia imbues it with stirring, transformative properties, while the space of emplacement lulls us into the secure rhythms of everyday life. Foucault characterized spaces of emplacement as cosmologically secure. Whether we enjoy such spaces or not, we feel confident that we know where they are, how they operate, how they relate to other spaces, and so on: "There were places where things had been put 
because they had been violently displaced, and then on the contrary places where things found their natural ground and stability" $(1986,22){ }^{4}$

But what about spaces where it is not difference but a sense of sameness that impacts the observer? I call such spaces "homotopias," from Greek ó $\mu$ ó, conveying the sense of "sameness" rather than "difference" (Liddell and Scott 1996, 1227). The second decade of the twenty-first century will perhaps prove to be the age of the homotopia. When Trumpsupporters say "Make America Great Again," or UKIP-supporters in Britain say "we want our country back,"5 or Dansk Folkeparti-supporters in Denmark say "Giv os Danmark tilbage" (Give us back Denmark), how are they imagining their territories will look once they are "reclaimed"? One can be near certain that they imagine America, Britain, and Denmark respectively as mono-cultural idylls, in many cases populated solely by people who not only share the imaginer's sense of ethnic identity, but possibly also have the same sexual mores, class identity, and lifestyle. The popularity of the aforementioned sentiments testifies that sameness can be just as emotionally compelling as difference. If Foucault's heterotopia is a space infused with the power of difference, then the homotopia is a space infused with the power of sameness.

\section{Kirsten Hastrup and Michel Foucault: innangarðs and útangarðs}

It would not be controversial to suggest that scholarship on Old Norse topics has generally been resistant to the type of "theory" of which Foucault has become emblematic (e.g., Foote 2004, 199-200; Wawn 1992, 223). But Old Norse scholars have often created penetrating theories of their own, founded upon detecting themes in certain texts, and then fashioning from those themes an apparatus that facilitates new conclusions about other texts. So it was that in 1981 the anthropologist Kirsten Hastrup published an article in which, like Foucault before her, she identified two discrete types of space. ${ }^{6}$ On the basis of a close reading of Snorra Edda (c. 1220s) and the Old Norwegian and Old Icelandic law codes (1100s-1200s), Hastrup suggested that in the Old Norse-speaking world all locations could be categorized as either innangarðs (of the inside of the garðr) or útangarðs (of the outside of the garðr). The $g a r ð r$-element referred to the perimeter of the traditional Icelandic farmstead, although garðr also had connotations of a fence or citadel, as in Ásgarðr, the fortress of the gods, or Garðaríki, "the country of citadels," i.e. Russia. What was innangarðs could be considered familiar and safe, and whatever was útangarðs was hostile and transgressive - the Old Norse equivalent, perhaps, of French outré. Hastrup later summarized her schema in an encyclopedia article:

[T] he central space was defined as controlled and familiar, while the peripheral space was uncontrolled and alien. Inside, law and peace reigned; outside lawlessness and war flourished.

... Clearly, the "outside" is associated with danger and lack of control. Once man left the social space defined by the law, he was reclassified as wild. Outside was also the space where the supernatural powers reigned, and where man had to capture them if he was to direct these forces to some purpose. Thus, there was a notion of setja úti til fróðleiks ("to sit out for wisdom"). Sitting out for wisdom implied that man temporarily left the social and voluntarily entered the wild to get into contact with the supernatural forces. "Wisdom" in this sense meant magical knowledge about, for instance, how to waken ghosts. (Hastrup 1993, 109)

The categories of heterotopia and homotopia do not map neatly onto the contours of innangarðs and útangarðs. The sense of unfamiliarity and flux intrinsic to heterotopias means 
that they will invariably correspond to the útangarðs designation. However, the space that is útangarðs is strange simply because it is far away, while the heterotopia is strange because of its diversity or its internal contradictions. Foucault's "space of emplacement" corresponds perfectly to the innangarðs category. But it is not entirely accurate to say the same of homotopias. In the estimation of both Hastrup and Foucault, familiarity cannot have transformative properties. Therefore, both the space of emplacement and the archetypal garðr are mundane: places of emotional and metaphysical stability. (This is not to say that disruptive experiences cannot arise in domestic settings, but such experiences disqualify those settings as spaces of emplacement.) The homotopia is a space predicated on sameness and domesticity, but unlike Hastrup's garðr and Foucault's space of emplacement, it is anything but emotionally neutral.

\section{Heterotopian Iceland in Landnámabók and Íslendingabók}

If Foucault had been amongst the first settlers who arrived in Iceland in the ninth century, he would no doubt have recognized the island as a flawless example of a heterotopia. As the cliché of modern tourist announcements often makes clear, Iceland is a place of fire and ice: one can watch a volcanic lava-flow against the backdrop of a soaring glacier, or sit in a near-scalding thermal pool while surrounded by snow. This quality of a space given a sense of drama by the marriage of binary oppositions would alone be a preliminary qualification for the status of heterotopia. More than that, however, there must have been a tremendous sense of cultural diversity. As seen, heterotopias do not have to be defined by multiculturalism, though multicultural spaces do tend to qualify as heterotopian on account of their sense of difference, exoticism, and, sometimes, alienation (Nagle 2009, 93-96).

Two of the earliest national histories of Iceland communicate precisely such a heterotopian image. One is the anonymous Landnámabók (early 1100s), and the other is Íslendingabók (1122-1132) by Ari Porgilsson. For example, Landnámabók is one of the handful of Old Norse sources which acknowledges Iceland's volcanic activity - a phenomenon about which, as Falk points out, the canonical Íslendingasögur "sagas of Icelanders" seem to be strangely in denial: "The entire corpus of Family Sagas, thirteen thick volumes'-worth in the standard modern editions, seems to know nothing of lava and ash plumes" $(2007,6){ }^{7}$ Landnámabók embraces Iceland's weird geology and tells the following volcanic-vignettecum-ghost-story about Pórir Grímsson:

Pá var Pórir gamall ok blindr, er hann kom út síð um kveld ok sá, at maðr røri útan í Kaldárós á járnnǫkkva, mikill ok illiligr, ok gekk par upp til bœjar pess, er í Hripi hét, ok gróf par í stǫðulshliði; en um nóttina kom par upp jarðeldr, ok brann pá Borgarhraun. Par var bœrinn, sem nú er borgin. ${ }^{8}$ (Landnámabók 1968, 98) ${ }^{9}$

Pórir was old and blind when he came outside late in the evening and saw that a large and ugly man was rowing out in the Kaldárós [river mouth] in an iron vessel, and he went up to the farmstead which was called Hripur, and dug up the gate of the milking pen. And that night "earth-fire" came up, and then burnt up Borgarhraun [a lava-field]. The hill is now where the farmstead used to be.

The sense that Landnámabók normally conveys regarding supernatural activity in Iceland is that occurrences such as the above are a natural part of life. Landnámabók offers a history of the first Icelanders and their farmsteads, told for an Icelandic audience, yet it appears to revel in the strangeness of the people and their land rather than their greatness. A later annotation, probably deriving from the lost Styrmisbók recension (Hermann Pálsson and 
Edwards 1972, 6-7) appears to be overcompensating for this tendency by adding the following to the text:

pat er margra manna mál, at pat sé óskyldr fróðleikr at rita landnám. En vér pykjumsk heldr svara kunna útlendum mǫnnum, pá er peir bregða oss pví, at vér séim komnir af prælum eða illmennum, ef vér vitum vist várar kynferðir sannar, svá ok peim mǫnnum, er vita vilja forn frœði eða rekja ættartǫlur, at taka heldr at upphafi til en họggvask í mitt mál, enda eru svá allar vitrar pjóðir, at vita vilja upphaf sinna landsbyggða, eða hvers hvergi til hefjask eða kynslóðir. (Landnámabók 1968, cii)

It is the opinion of many men that it is superfluous knowledge to write about the land-claims. But we rather intend to be able to reply to foreigners when they accuse us of being descended from slaves or villains, if we know with certainty our true heritage, and also for those men who wish to know of ancient learning or to reckon lineages, one should rather pick up at the beginning than strike upon the middle of a thing. In any case all learned nations are thus: [they want] to know the beginning of their settlements, or how their generations came to be.

Landnámabók is also frank about Iceland's ethnic diversity. The substantial Celtic element is well-known, accounting for stereotypically rebellious Celtic slaves, pious Celtic Christians, and a noble Norse-Celtic elite (Sayers 1994, 129-52; cf. Hermann Pálsson 1996, esp. 47-102). But Landnámabók also records settlers from farther afield than Ireland. One settler, Hroskell Porsteinsson, brought with him a wife, Jóreiðr Qlvisdóttir, who was said to be the daughter of the Sápmi Finnakonungr (King of the Finns) Mọttull (1968, 82). Another, SleituBjǫrn Hróarsson, claimed descent from a Swede who had been married both to Elína, a Russian princess, and Ingigerðr, sister of Dagstyggr rísakonungr (King of the Giants) (1968, 197). Which woman was supposedly Sleitu-Bjorn's great-grandmother is not recorded. ${ }^{10}$ Geirmundr Heljarskinn is said to be the son of the daughter of the Bjarmakonungr (King of the Permians, 150-51), a story which Bergsveinn Birgisson has suggested may actually have reflected Geirmundr's Samoyed extraction (2013, esp. 123). One Friðleifr is said to be Geatish on his father's side (gauzkr at foðurkyni) and Flemish on his mother's (Landnámabók 1968, 242), a combination more likely in the high days of the Hanseatic League several centuries later than in Iceland of the late ninth century.

Íslendingabók portrays a similarly diverse society, with a clergy made up of Englishmen, Irishmen and Germans, ${ }^{11}$ and the famous case of three apparently Orthodox Christian missionaries, "brír ermskir: Petrus ok Abrahám ok Stephánus" (three Armenians: Petrus and Abraham and Stephanus; Íslendingabók 1968, 18). ${ }^{12}$ This last case is particularly revealing, as the Icelandic Grágás lawcode (c. 1117-1260s) explicitly guarantees the right to non-Roman observances: "ef byskopar koma vt higat til landz eða prestar sem eigi eru lærðir a latinu tungu huart sem peir eru ærmskir eða girzkir ok er monnum rett at hlyða a tiðir peirra ef vilia" (if bishops or priests come here to the country who are not learned in the Latin language, whether they are Armenian or Greek, people have the right to attend their services if they wish; 117). One might interpret the premise of Landnámabók and Íslendingabók as being that Iceland is a land of contradictions: the furthest north-western outpost of Christendom, and yet the only Latin polity which specifically permitted the furthest eastern forms of Christianity (Grágás, Skálholtsbók m.m 1974). The Iceland of these two sources, which are ostensibly foundational national histories, is both ethnically diverse and possesses an unfamiliar, magically-inflected landscape: difference is not a source of crisis, but the norm. Quelle hétérotopie! 


\section{Manufacturing the mundane: the farmstead as a means of production}

If Landnámabók and, to a lesser extent, Íslendingabók largely construe Iceland as a setting of strangeness, the narrative mode of the Íslendingasögur normally necessitates a rather different approach. Landnámabók is a catalogue of folkloric episodes. There is no over-arching plot which takes advantage of difference (weird landscape features, the supernatural, multicultural characters, etc.) in order to escalate the narrative. The Sagas of Icelanders, on the other hand, usually establish a degree of tension between the familiar and the strange. The backdrop of a typical Family Saga is something like Foucault's space of emplacement: quotidian, predictable, and domestic. Characters such as cunning Irish princesses, Swedish berserkers, or zombie-like draugar, are then intrusions that lead to plot developments. This dichotomy can be transposed onto the oppositions of familiar versus strange, natural versus supernatural, or realistic versus fantastic, as outlined by Margaret Clunies Ross:

The fantastic mode in the sagas frequently occurs precisely where there is some uncertainty as to the nature of reality, or where the social norms of the culture are subverted, or where the present confronts the past and the author needs to produce an explanation of how and why things have happened or people have acted in certain ways. (Clunies Ross 2002, 449-50)

Carl Phelpstead has noted that "the fantastic" is a mode that is liable to be misunderstood (2012, 27-29). Phelpstead illustrates that Clunies Ross, in the work from which the above quotation is drawn, faces the dilemma of whether "fantastic" is defined by its commonplace meaning, or by the more sophisticated (but not necessarily appropriate) theoretical sharpening of Tzvetan Todorov (1975). ${ }^{13}$ For our purposes, the vernacular sense of the fantastic is indicated here: the atmosphere of wonder, of being outside of normal experience, of experiencing a world which could in some way be a dream, either because that world has supernatural elements, or simply because its beauty is so enhanced that it is no longer a convincing likeness of day-to-day life. Torfi Tulinius offers a theory comparable to that of Clunies Ross on how the domestic/real and the strange/fantastic operate in opposition but also in tandem - to propel the narratives of the classic Íslendingasögur. He notes that the Sagas of Icelanders possess a strong tradition of "using the unreal to throw light on the real" (2011,24). Similarly, Clunies Ross notes that "the literary modes of the realistic and the fantastic are often juxtaposed in the medieval Icelandic textual representation of human experience" $(2002,453)$, although Phelpstead notes that for this juxtaposition to stand, one must be clear regarding what elements are being juxtaposed (2012, 28). I would propose, however, that there are cases in the Íslendingasögur where the backdrop - the site of the realist mode - is not serving as a mundane space of emplacement. Rather, settings that might otherwise be seen as familiar are instead presented as having transformative properties. In other words, my contention is that certain episodes in particular sagas construct their settings as homotopias. I take two farmsteads as my principal examples: Hlíðarendi, from Njáls saga (1270s-1290s), and Helgafell, from Eyrbyggja saga (1250s-1300).

Before undertaking a close reading of scenes from the aforementioned sagas, it is necessary to illustrate some of the valences that Icelandic farmsteads must have had for the Old Norse-speaking audiences of the Íslendingasögur. A modern reader may well have been raised in a city or town, or will at least be accustomed to the concentration of power and population in cities that characterizes the urban period of human history. Excepting the occasional sojourn to Nidaros or Constantinople, the world of the Family Sagas generally presents no urban landscapes at all. True to the historical reality of the Settlement Period, 
virtually all the action takes place either on farmsteads or on journeys between farmsteads. ${ }^{14}$ For a modern readership, this exclusively rural setting - excursions abroad notwithstanding - is decidedly alien. But for a medieval Icelandic audience, it must have been entirely normal. Indeed, as previously observed by Hastrup, the innangarðs quality of the farmstead provided a paradigm of familiarity and security.

The ubiquitous presence of the farmstead in the Íslendingasögur reflected life in the ninth to tenth century (when most sagas are set), but this ubiquity must also have been conditioned by the enduring economic hegemony of the Icelandic farmstead during the thirteenth century (when most sagas were written). As Vésteinn Ólason notes, "[t]he farm (bor) was a basic social and economic unit in Iceland" $(2003,222)$. The farmstead was not only where food was grown, but also the site of accommodation, smithies, artisans' workshops, and religious buildings, both in the pagan period with outbuildings for cultic purposes and, later, the Christian era with its boendakirkjur (farmers' churches; on which see Foote and Wilson 1970, 145-59).

The boer (plural boeir) in medieval Iceland thus totally encompassed the means of production; one assemblage facilitated all manner of transformations of basic resources into commodities, from staple foodstuffs to textiles and metalworking (Jón Jóhannesson 1974, 301-2; cf. Gunnar Karlsson 1975). Moreover, the bor was also the sole means of subsistence, that is, the source of the subset of commodities that laborers must have at a bare minimum in order to go about their work. In a modern capitalist economy the means of subsistence are usually distinguished from a personal participation in the means of production (Marx 1961-1967, 1:168-73). That is to say, the place we sleep is generally somewhere else than the factory or office where we sell our labor, ${ }^{15}$ and when we need a new jumper, for example, we have to leave the workplace in order to procure one. This was apparently not the case in medieval Iceland, where workers spent their whole lives in service to one or more boir.

Economically, the distinction between means of production and means of subsistence is useful for calculating the lowest possible wage one can pay a worker before he/she ceases to be productive, but it is otherwise of little importance (Marx 1976, 26-27). After all, a person employed on a grain farm does not necessarily care whether the grain he/she grows ends up in alcohol or in the stomachs of other grain farmers. Narratively, however, the distinction is quite crucial, because it determines how many hours of the day feel as though they are our own, versus how many feel as if they are being expended only in order to uphold the social order in which we currently find ourselves. Or, phrased another way, how and where our labor is used determines how much we feel as though we are working to live or living to work, even if our actual degree of autonomy would be the same regardless. When considering how given medieval authors depicted boir, and how medieval audiences might have reacted emotionally, it is important to remember the omnipresence of the boer in Icelanders' lives. When we finally call a halt to the day's toils from our jobs in office complexes, industrial estates, or university campuses, and pick up an Icelandic saga for some after-work entertainment, we are transported to a foreign place with a foreign means of production. We therefore inevitably relate to the settings of the sagas in a very different manner to when a medieval Icelander completed their day's toils on an Icelandic farmstead, to hear the recitation of a saga set on another Icelandic farmstead. (As will become evident, I subscribe to the view that a great many sagas, particularly the Íslendingasögur, were read aloud to socially-mixed groups, as suggested by Lethbridge 2016, 72-73; see also Mitchell 
1991, 91-107; O’Connor 2002, 15-19). Under these conditions, how did the authors of Njáls saga and Eyrbyggja saga elevate their settings from spaces of emplacement to homotopias? How did they make the farmstead capable of eliciting strong emotional responses, and what were the political implications of doing so?

\section{Helgafell and Hlí̉arendi: making the domestic wonderful}

Previously, it was my contention that the farmsteads of the Íslendingasögur are generally spaces of emplacement: mute, passive backdrops that stand in opposition to the drama that unfolds in front of them. I will focus my discussion on two of many possible examples. In Grettis saga (c. 1310-1320), the farm of Porhallsstaðir is the backdrop for the fight between the Swedish draugr, Glámr, and the eponoymous hero, Grettir Ásmundarson. Porhallsstaðir has an object relationship (in the grammatical sense) to the characters: a cairn is built on it, Glámr's blood is shed over it, etc. It is affected by the actions of the protagonists, but it does not affect them in return. The case of the farms of Sæból and Hóll in Gísla saga Súrssonar (1220s-1250s) exhibits a still stonier indifference. Hóll is the backdrop for the slaying of Vésteinn Vésteinsson, murdered in his bed by an unknown assailant. Sæból is the backdrop for the murder of Porgrímr, murdered by Gísli Súrsson shortly after Gísli fondles Porgrímr's wife - Gísli's sister - in their marital bed. The stories are suspenseful, but the scenery is silent.

The case of Hlíðarendi in Njáls saga therefore provides an arresting contrast to porhallsstaðir, Hóll, and Sæból. In the scene we are about to examine, Gunnarr Hámundarson has become embroiled in a bloody feud with Gizurr hvíti Teitsson, and so he must leave the country if he is to escape Gizurr's vengeance. Gunnarr's closest friend, Njáll Porgeirsson, has warned him that "ef pú ferr eigi utan ok rýfr sætt pína, pá muntú drepinn vera hér á landi, ok er pat illt at vita peim, er vinir pínir eru" (if you do not leave and [thereby] break your peace accord, then you will be killed here in this country, and that will be an awful thing to hear for those who are your friends; 181). Gunnar and his brother Kolskeggr make ready to go into exile:

Annan dag eptir býr hann snemmendis ferð sína til skips ok sagði pá ǫllu liði, at hann myndi ríða í braut alfari, ok pótti mǫnnum pat mikit, en væntu pó tilkvámu hans síðar. Gunnarr hvefrr til allra manna, er hann var búinn, ok gengu menn út með honum allir. Hann stingr niðr atgeirinum ok stiklar í sǫðulinn, ok ríða peir Kolskeggr í braut. Peir ríða fram at Markarfljóti, pá drap hestr Gunnars foeti, ok stọkk hann ór sǫðlinum. Honum varð litit upp til hlíðarinnar ok boejarins at Hlíðarenda ok mælti: "Fọgr er hlíðin, svá at mér hefir hon aldri jafnfọgr sýnzk, bleikir akrar ok slegin tún, ok mun ek ríða heim aptr ok fara hvergi." "Ger pú eigi pann óvinafagnað," segir Kolskeggr, "at pú rjúfir sætt pína, pví at pér myndi engi maðr pat ætla. Ok máttú pat hugsa, at svá mun allt fara sem Njáll hefir sagt." "Hvergi mun ek fara," segir Gunnarr, "ok svá vilda ek, at pú gerðir." (Njáls saga 1954, 182-83)

Early the next day he [Gunnarr] prepares for his journey to the ship and told all the men that he would ride away for good, and people thought that was a big deal, but they hoped he would come back later. ${ }^{16}$ Gunnarr embraces everyone, and when he was finished everybody exited with him. He sticks his halberd into the ground and hops into the saddle, and he and Kolskeggr ride away. They ride until they get to Markarfljótur, then Gunnar's horse trips over its own feet, and he tumbles out of the saddle. He turned to face the hillside and the farm at Hlíðarendi, and said: "The hillside is beautiful, so much so that it has never seemed so beautiful, pale fields and freshly cut hay. I will ride back home and go nowhere." "Don't do this, playing into the hands of our enemies," says Kolskeggr, "you'll break the peace accord you made, and nobody wants 
that. And think, everything will go just like Njáll said." "I’m not going anywhere," Gunnarr says, "and I wish you would do the same."

The scene is remarkable because it depicts actual landscape features exerting agency over human characters. Gunnarr finds himself stirred by an Iceland imbued with transformative emotional properties. It is one of an extraordinarily small number of scenes in the sagas that indicates that anybody in the Middle Ages found themselves mesmerized by the Icelandic landscape in the manner that both natives and tourists do today. As David Ashurst notes, "appreciative references to natural beauty, common enough in the romance genre, do not appear to be typical of the family sagas, the group to which Njáls saga belongs" (2000, 274). Some very sound scholarship has been done in the past decade, arguing that Icelanders did have a profound appreciation of their landscapes, and that this appreciation had an impact upon saga writing (e.g., Barraclough 2012, Lethbridge 2016, esp. 54-58) However, these interventions must rely on the saga-writers' interest in place names and etiological legends, occasionally inflected by modern theoretical breakthroughs, such as geopiety, or Chris Tilley's work on landscape studies (Barraclough 2012, 79-81; Overing and Osborn 1994, 57-59). That is to say, the scholar who wants to locate an esteem for landscape in the sagas frequently has to start by redefining what a landscape is (e.g., Barraclough 2012, 80-81n3; cf. Waage 2012, 177-78). It must be stressed that this is not always the case. Edda Waage provides an analysis of the Old Norse term landsleg which "indicate[s] that landscape, regarded as natural inland scenery, was an object of aesthetic experience long before the artistic works of the Renaissance and Romanticism" $(2012,189) .{ }^{17}$ Waage $(2012$, 183-88) takes examples from Eiríks saga rauða (1260s), Króka-Refs saga (1300s), Reykdoela saga (1230s-1240s), and Vatnsdcela saga (c. 1250s-1260s). The aforementioned examples are generally limited to just one sentence in their source texts, while the scene from Njáls saga cited above is unique in its vivid explication of just how affected Gunnarr is by the aesthetic qualities of the landscape.

The singularity of the scene might militate for the suggestion that this is a foreign borrowing, drawn from a continental model, rather than the product of an indigenous sensibility. It has been suggested that the saga author was influenced by Alexanders saga (c. 1262), the Old Norse translation of the Latin Alexandreis by Walter of Châtillon (1100s). Traditionally, the argument in this direction has been made on lexical grounds (Einar Ól. Sveinsson 1954, xxxvi; Lönnroth 1976, 153-54). Gunnarr in Njáls saga admires the bleikir akrar (pale fields) of Hlíðarendi, while Alexander the Great admires the bleika akra (same phrase in the accusative case) of Asia Minor in Alexanders saga $(1925,14)$. Outside of these two attestations, the phrase is not found anywhere else in the Old Norse corpus. However, as Ashurst has shown, bleikir akrar may well be one among many phrases which occurs once in Alexanders saga and once in more native genres, such as Eddic verse or samtíðarsögur (Ashurst 2000, 273-78). Rather than a case of borrowing, it is therefore just as likely that Njáls saga and Alexanders saga are two sources that preserve a once common verbal pairing (Ashurst 2000, 277-78). Gunnarr's admiration for Hlíðarendi may be highly unusual, but that does not mean it had neither roots in - nor implications for - the experience of a medieval saga-audience.

The sight that stirs Gunnarr is not just beautiful - it is familiar. He has spent most of his life in and around the farm. For a moment, Hlíarendi has become the diametric opposite of a heterotopia. The place is so emotionally compelling to Gunnarr that he will sacrifice his 
life to stay there, but it cannot in any way be said that it is space characterized by diversity or strangeness. It is, then, a homotopia. Regardless of whether there is any genealogical relationship between Alexanders saga and Njáls saga, Gunnarr and Alexander considered together provide an illuminating contrast. Alexander looks across the Dardanelles, to a new world of exotic riches and opportunity. Strange peoples and fantastic monsters await him in this foreign land - he cannot resist the allure of the heterotopia he sees on the other side of the Bosphorus. Meanwhile, in Njáls saga, Gunnarr gazes upon his home, and decides it is better to stay and die than to go abroad and live (cf. Ashurst 2000, 278).

A second - more fantastic and less straightforward - example of a landscape-feature exerting agency over saga characters is the case of Helgafell in Eyrbyggja saga. Helgafell (Holy Mountain) is a seventy-three-meter elevation on the Snæfellsness peninsula in Western Iceland. ${ }^{18}$ The Helgafell mythos must have begun as a simple iteration of the Norwegian and Sápmi folk belief that hills are abodes of the dead (Boberg 1966, 99; Ström 1958, 437). Specifically, there was a notion that certain hills are associated with certain family lines, so that everyone of that lineage enters the hill spiritually after they die. (Indeed, I once met a farm-owner in Gudbrandsdalen who claimed to maintain just such a belief regarding the hill opposite his farm, which had been held by the same male line since at least 1343). ${ }^{19}$ In Eyrbyggja saga, Helgafell is first introduced in the fourth chapter - at an unusually early point in an Íslendingasaga for an element or character that will go on to recur throughout the plot:

Pórólfr kallaði Pórsnes milli Vigrafjarðar ok Hofsvágs. Í pví nesi stendr eitt fjall; á pví fjalli hafði Pórólfr svá mikinn átrúnað, at pangat skyldi enginn maðr ópveginn líta ok engu skyldi tortíma í fjallinu, hvárki fé né mǫnnum, nema sjálft gengi í brott. Pat fjall kallaði hann Helgafell ok trúði, at hann myndi pangat fara, pá er hann dœi, ok allir á nesinu hans frændr. (Eyrbyggja saga 1935,9$)$

Pórólfr named the area between Vigrafjörður and Hofsvágr Pórsnes [Thor’s Headland]. On that headland stands a mountain; Pórólfr had so much belief in that mountain that no man could look upon it unwashed and there should be no slaughter on the mountain, neither of cattle nor men, unless it expire of natural causes. He called that mountain Helgafell [Holy Mountain] and believed that he would go there when he died, as would all his kinsmen on the headland.

The saga goes on to relate that Pórólfr, an enthusiastic devotee of the god Pórr, establishes an assembly (ping) in the vicinity. He also deems the area "svá mikill helgistaðr, at hann vildi með engu móti láta saurga vǫllin, hvárki í heiptarblóði, ok eigi skyldi par álfrek ganga” (such a great holy place that he would in no way let the ground be defiled in any way, not by bloodshed, and people should not go there to do their "elf-shockers" [i.e. toilet]; 1935, 10). ${ }^{20}$ Helgafell went on to refer both to the holy hill itself, and the farmstead (boer) beneath it. A number of theoretical lenses might be deployed to scrutinize Pórólfr's feelings about Helgafell. Émile Durkheim's structuralist paradigm of sacred versus profane, for example (see Wanner 2009, esp. 220-26; Sundqvist 2015, 292-94), or perhaps attention might be drawn to Pórólfr's connection of power to place: his land is holy, and his land is where the ping will be (e.g. Sundqvist 2015, 177-79). In this instance, however, the dichotomy of strangeness and familiarity is most pertinent. Like Hlíðarendi, Helgafell, as an assemblage of a farmstead and a magical mountain, is a space of emplacement, paradoxically charged with transformative power. ${ }^{21}$ Helgafell is not an enchanted fairy-tale castle, a distant land full 
of exotic beings. It is an ordinary Icelandic farm - a place where everyday labor is carried out - which is nonetheless being depicted as fantastic. It is, then, a homotopia.

The text from Eyrbyggja saga cited above is virtually identical to the excerpt describing Helgafell in Landnámabók $(1968,125)$. It was almost certainly borrowed from there, and had the saga author contributed no further information the appearance of Helgafell would have remained a similar sort of self-contained folkloric gem to those which make up the mosaic of Landnámabók. But Helgafell, like Hlíðarendi, goes on to exert agency over characters in the sagas. As Mayburd puts it, "they belong to it and are subject to its power as much as it belongs to them as part of their familial territory" $(2014,132)$. Unlike Hlíðarendi, there is no aesthetic meditation on the beauty of its landscape, but there is still a sense that this is a bor with curious emotional - perhaps even magical - powers. In chapter eleven of Eyrbyggja saga, the following vignette is told concerning Porsteinn Cod-biter, son of Pórólfr the pious pagan:

Pat var eitt kveld um haustit, at sauðamaðr Porsteins fór at fé fyrir norðan Helgafell; hann sá at fjallit lauksk upp norðan; hann sá inn í fjallit elda stóra ok heyrði pangat mikinn glaum ok hornaskvǫl; ok er hann hlýddi, ef hann næmi nǫkkur orðaskil, heyrði hann, at par var heilsat Porsteini porskabít ok fọrunautum hans ok mælt, at hann skal sitja í ǫndvegi gegnt feðr sínum. Penna fyrirburð sagði sauðamaðr Póru, konu Porsteins, um kveldit; hon lét sér fátt um finnask ok kallar vera mega, at petta væri fyrirboðan stœrri tíðenda. Um morguninn eptir kómu menn útan ór Hǫskuldsey ok soggu pau tíðendi, at Porsteinn porskabítr hafði drukknat í fiskiróðri[.] (Eyrbyggja saga 1935, 19)

One evening in the autumn, a shepherd of Porsteinn's went up to the cattle to the north of Helgafell. He saw that the mountain opened up on its northern face. Inside the mountain he saw great fires and heard from there much merriment and clinking of drinking horns, and when he listened to see if he could make out any words he heard that Porsteinn Cod-biter and his company were being welcomed, and told that he [Porsteinn] should sit in a highseat next to his father. The shepherd told this portent to Póra, Porsteinn's wife, in the evening. She didn't appear moved, and declared it could well be a foreshadowing of bigger news. In the morning afterwards people came from Hoqskuldsey and told them the news, that Porsteinn Cod-biter had drowned on a fishing expedition.

Who decides that Helgafell will open up? The Old Norse phrase used is lauksk upp - a reflexive construction (i.e., "it opened itself up"). Without additional evidence this detail alone is not significant, as the Old Norse phrase for "opening up" is always given in the reflexive, even if the relationship described is in reality transitive. Nonetheless, it may well be that Helgafell actually is acting as an independent character. It is presumably not Porsteinn Cod-biter who has decided to reveal the scene to the shepherd, as he has only just arrived inside the mountain and so presumably does not have any office there until he takes his place on his high-seat ( $i$ ondvegi). One might suspect that Pórólfr has made the decision to reveal the vision to the shepherd. However, if so, why not be more direct, perhaps by addressing the shepherd personally, rather than letting him eavesdrop? Instead, one gets the impression that Pórólfr and Porsteinn are totally unaware of the shepherd. If so, it is not unreasonable to adduce that Helgafell itself chose to deliver the vision.

Helgafell also appears to influence the plot of the saga in chapter twenty-eight. By this point in the saga the principal hero has emerged - Snorri "the chieftain" goði - who is pórólfr's great-grandson. Snorri's friend Styrr has a problem: a pair of Swedish berserkers have arrived at his farm, causing a great deal of nuisance, and one of them wishes to marry 
Styrr's daughter, Ásdís. Styrr is not overly thrilled at this prospect, and so he approaches Snorri to seek his guidance:

Um morguninn eptir reið Styrr inn til Helgafells. Ok er hann kom par, bauð Snorri honum par at vera, en Styrr kvazk tala vilja við hann ok ríða síðan. Snorri spurði, ef hann hefði nǫkkur vandamál at tala. "Svá pykki mér," segir Styrr. Snorri svarar: "Pá skulu vit ganga upp á Helgafell; pau ráð hafa sízt at engu orðit, er par hafa ráðin verit." Síðan gengu peir á fjallit upp ok sátu par á tali allt til kvelds; vissi pat engi maðr, hvat peir tǫluðu. Síðan reið Styrr heim. (Eyrbyggja saga 1935, 71-72)

The next morning Styrr rode inland to Helgafell. And when he arrived there, Snorri invited him to stay, but Styrr declared he wished to talk with him then ride. Snorri asked if he had some difficult business to discuss. "So it seems to me," says Styrr. Snorri replies: "Then we two should go up onto Helgafell. When plans have been made there they have seldom come to nothing." Then they walk up on the mountain and sat there in discussion until the evening. No man knew what they discussed. Then Styrr rode home.

The plan that Styrr is given involves locking the berserkers in a sauna. One is killed as he breaks out, and the other is then forced back inside to meet a ghastly, sweaty end. With her Swedish suitors out of the way, Ásdís then marries Snorri goði himself. But from where does this successful scheme spring? Is it entirely the product of Snorri's cunning? In that case the phrase "pau ráð hafa sízt at engu orðit, er par hafa ráðin verit" (when plans have been made there they seldom come to nothing) would merely be an expression of Snorri's humility, i.e. Snorri would be pretending that the plan comes from the mountain, when really it is his own ingenuity. Torfi Tulinius has suggested that the dead ancestors inside Helgafell may have acted as advisors while Snorri and Styrr plotted $(2006,966)$. This is highly plausible, but given the suggestion that Helgafell itself possesses some sort of agency and intelligence, as suggested by Mayburd and, indeed, by Snorri's own words, it is not impossible that the author of Eyrbyggja saga intended their audience to understand that the place itself was somehow contributing its own wisdom. The belief that Helgafell could indicate its plans to chosen observers persists into sagas set in the Christian period too, as in this scene in Laxdoela saga (c. 1230-1250):

Osvífr var grafinn at Helgafelli, pví at Guðrún hafði par pá látit gera kirkju. Á peim sama vetri fekk sótt Gestr Oddleifsson, ok er at honum leið sóttin, pá kallaði hann til sín Pórð lága, son sinn, ok mælti: "Svá segir mér hugr um, at pessi sótt muni skilja vára samvistu. Ek vil mik láta fœra til Helgafells, pví at sá staðr mun verða mestr hér í sveitum; pangat hefi ek opt ljós sét." (Laxdcela saga 1934, 196)

Osvifr was buried at Helgafell, because Guðrún had had a church built there. This same winter Gestr Oddleifsson fell sick, and as the sickness wore one, he then called Pórðr the Short, his son, to see him, and said: "Something inside tells me that this sickness will be the parting of our company. I want to be brought to Helgafell, because this place will become the greatest in the district; I have often seen a light there."

There are obvious realpolitische concerns shaping the author of Laxdoela saga's treatment of Helgafell here. As Haki Antonsson notes, Helgafell would go on to be the site for an Augustinian priory $(2012,100,114-15)$. But for the purposes of the present study, it is more important to note the will-o'-the-wisp which Gestr has repeatedly seen over the farmstead. Like the vision of the ancestors dining or the advice given to Styrr in Eyrbyggja saga, a potential reading of Gestr's experience is that Helgafell has its own knowledge about and plans for - the future. It is especially likely that Helgafell itself is at work here, not any spectral ancestors, because Gestr Oddleifsson is not of Pórólfr's male line. In fact, he has 
no familial ties to the owners of the farmstead at all. Once more, a saga author takes a boer which otherwise might be a mute space of emplacement, and transmutes it into a homotopia: a space that has the powers of a heterotopia, but derives them from familiarity rather than diversity. The potency of the saga author's recasting has apparently been long-lived. Paul Schach describes how a thirteenth-century saga influenced his own understanding of the landscape:

With the possible exception of Pingvellir, there is no region in Iceland which invokes in me such a keen feeling of timelessness [as Helgafell], an almost eerie awareness of the past living on in the present. To a considerable degree the sensation of déjà vu experienced upon first catching sight of such historic landmarks as Helgafell and the constant consciousness of the coalescence of past and present are due to the unique character of Eyrbyggja saga. (Schach 1972, 113-14)

Schach's experience was most likely different to that of a medieval Icelander: he did not grow up in Iceland, nor make his living on a bor (he was a professor of Germanic philology, hailing from Pennsylvania). Helgafell must have been more like a heterotopia than a homotopia - something novel and newly seen, rather than routine but re-imagined. When Foucault gives an account of the ability of the heterotopia to skew one's perception of time, he could very well be describing Schach's sensation:

Heterotopias are most often linked to slices in time - which is to say that they open onto what might be termed, for the sake of symmetry, heterochronies. The heterotopia begins to function at full capacity when men arrive at a sort of absolute break with their traditional time $(1986,26)$.

But would a homotopia not also entail weird chronotropic effects? One would certainly expect so, given that the homotopia otherwise assumes the effects of the heterotopia, even though it arrives at them by totally inverted means. This expectation is confirmed by the examples hitherto presented. Gazing up from the dirt at Hliðarendi, Gunnarr forgets his sensible rush to escape the country. The blades of his enemies' weapons belong to another time, one quite outside the trance in which he is absorbed. Inside Helgafell, those long-dead drink forever, unbothered by the accumulating weight of passing years.

It ought to be acknowledged that the aforementioned scenes concerning Hlíðarendi and Helgafell convey multiple messages, for instance Gunnarr's romanticism, the irresistibility of folkloric tradition, and the importance of the religious house at Helgafell. But tied up with all of them is the sense that the ordinary Icelandic boer does not have to be quite so ordinary. The familiar, domestic space where medieval Icelanders worked in the fields, churned dairy, and produced commodities could also be stirring and magical. They could exhibit such beauty that a man would die to stay there for just a few more days, or they could possess an autonomous will which turned them from mundane backdrops into wondrous beings. Like the nationalist's imagined vista of England, the landscape could become a series of aesthetic idylls rather than economic units: to borrow from William Blake, "pleasant pastures seen" rather than "dark Satanic mills."

\section{Labor and landscape: homotopias as opiates for alienation}

What might the audience's response have been to the construction of the bor as a homotopia in the Íslendingasögur? Homotopias are essentially aesthetic insofar as they stir emotions rather than prompt cold reasoning. However, their predication on the opposition of difference and familiarity means that they also tend to have strong political resonances. In our own time, these have often been of a jingoistic bent. Arguably homotopias were 
occasionally capable of being so in the Middle Ages too (e. g., Cole 2015b, 136-73); however, the cases presented in this study indicate a different political implication. To reconstruct this implication, we must also reconstruct an audience for our sagas: a fraught but necessary exercise. As previously mentioned, I subscribe to the view that sagas such as Eyrbyggja saga and Njáls saga, like the fornaldarsögur (and a good many other genres besides) were read aloud. ${ }^{22}$ Following Peter Foote (1984, 47-49), I agree that the audiences for such readings were often socially diverse. As Foote notes, knowledge of historical conditions in medieval Iceland supports this view, as do post-medieval observations of saga-readings. In a case cited by O'Connor $(2002,16)$, Ebenezer Henderson tells the following vignette from a bor in 1814-1815. Here, the sagaman reads both to landowners and servants (where "servants" most likely also includes "agricultural servants," as in eighteenth-century usage):

A winter evening in an Icelandic family presents a scene in the highest degree interesting and pleasing. Between three and four oclock, the lamp is hung up in the badstofa, or principal apartment, which answers the double purpose of a bed-chamber and sitting-room, and all the members of the family take their station. ... The master and mistress, together with the children, or other relations, occupy the beds at the inner end of the room; the rest are filled by the servants. The work is no sooner begun, than one of the family, selected on purpose, advances to a seat near the lamp, and commences the evening lecture, which generally consists of some old saga, or such other histories as are to be obtained on the island. (Henderson 1819, 283; emphasis mine)

Continuities between the Icelandic Middle Ages and the Early Modern/Modern period can be overstated, but there is no reason to suspect substantial differences in the fundamentals of boer culture between 1215 and 1815. Iceland during Henderson's visit was still largely pre-urban, and still predominantly reliant on agriculture, even though a Danish trade monopoly and the victory of Lutheranism would have otherwise constituted important contrasts with the medieval experience.

My interest is in how the homotopia might have been received (or been intended to have been received) by "the servants at the outer end of the room." Were it not for their construction as homotopias by the authors, Hlíðarendi and Helgafell might be seen to be utterly lacking in escapist potential. There are genres outside of the Íslendingasögur which are set in exciting foreign locales, full of strange creatures and fantastic heroes - such as the fornaldarsögur (sagas of ancient times, also known as the "heroic sagas"), the lygisogur (lying sagas), or native romances, which are usually pastiches of foreign chivalric tales and indigenous legends. Sheryl Werronen $(2013,141-46)$ notes that the settings of this latter genre in particular tend to be heterotopias in the Foucauldian sense. Turning the beer from a space of emplacement into a homotopia, by giving it a sense of agency and commenting on its natural beauty, is a way to make the mundane as compelling as these exotic genres. An audience who is born on a beer, lives on a beer, works every day on a bor and will probably die on one too, is suddenly a given a chance, like Gunnarr, to look upon their familiar surroundings in a new light.

Creating homotopias also resolves the potential tension between the fundamentally aristocratic outlook of most Íslendingasögur and what might be thought of as the proletarian status of a portion of their audience. Both Eyrbyggja saga and Njáls saga begin with the character of Auðr "the deep-minded" djúpúðga. Auðr is the daughter of Ketill "Flatnose" flatnefr, an eighth-century power magnate from Norway, who is driven into exile by the rise of King Haraldr "Fairhair” Hárfagri. Although Auðr and her descendants are presented as 
plucky émigrés, surviving by their wits, they are obviously from the outset noble, wealthy, and powerful. On the whole, the Íslendingasögur are stories about people who own land not people who have no option but to work on other people's land (Cole 2015a, 40). When landless laborers do appear in the Íslendingasögur, they are generally nameless shepherds, with a limited narrative role and life expectancy. ${ }^{23} \mathrm{Often}$, the opening of an Íslendingasaga is an iteration of the "Icelandic dream": like the "American dream," a usually illusory promise that the elite have earned their position through hard work alone, and that anybody, no matter how lowly, can follow in their footsteps.

Without the magic of the homotopia, I would posit that the boer ought to have been seen by agricultural laborers as uninteresting, and quite probably also alienating (in a Marxian sense). Marx defined alienation as the process by which people relinquish their personal connection to the products of their labour. As Marx put it:

... let us take a look at [Robinson Crusoe] on his island ... some few wants he has to satisfy, and must therefore do a little useful work of various sorts.... In spite of the variety of his work, he knows that his labour, whatever its form, is but the activity of the one and same Robinson. (Marx 1961-1967, 1:76)

Crusoe thus works to feed his immediate appetites. However, under an alienated system of labor, man works to feed the appetites of others. He works to produce food or wealth for another, who will then reward him with a degree of food or wealth less than what the laborer has personally produced. Under these conditions:

labour is external to the worker, i.e. does not belong to his essential being; that he therefore does not confirm himself in his work, but denies himself, feels miserable and not happy. ... Hence the worker feels himself only when he is not working; when he is working he does not feel himself. $\mathrm{He}$ is at home when he is not working, and not at home when he is working. (Marx 1975, 326)

How true was this of medieval Iceland? Santiago Barreiro notes that Egils saga (1220-1240) demonstrates a basic understanding of the:

difference between labour, land and other goods ... [in the saga] the labour from and the land claim of Egill's family did not generate wealth that could be in any meaningful way dissociated from a sense of moral and legal superiority. $(2015,32)$

There is a further, starker example of alienated labor elsewhere in the Íslendingasögur, namely in Hrafnkels saga Freysgoða (1250s-1260s). In the following scene, Porbjorn, an unsuccessful smallholder, tells his son, Einarr, that he must now go and provide his labor to another boer in order to survive:

Porbjǫrn átti fé lítit, en ómegð mikla ... Pat var á einu vári, at Porbjǫrn mælti til Einars, at hann mundi leita sér vistar nọkkurar, - "pví at ek parf eigi meira forvirki en petta lið orkar, er hér er, en pér mun verða gott til vista, pví at pú ert mannaðr vel. Eigi veldr ástleysi pessari brottkvaðning við pik, pví at pú ert mér parfastr barna minna. Meira veldr pví efnaleysi mitt ok fátœkð. En ǫnur bǫrn mín gerask verkmenn. Mun pér pó verða betra til vista en peim.” Einarr svarar: "Of síð hefir pú sagt mér til pessa, pví at nú hafa allir ráðit sér vistir, pær er beztar eru, en mér pykkir pó illt at hafa órval af." (Hrafnkels saga 1950, 100-101)

porbjorn had little wealth, but a large family. ... One spring, Porbjǫrn said to Einarr that he would have to find a position for himself "because I have no more need for farmwork than these men who are here do, but you will find it easy to get lodging because you are very competent. This parting from you is not caused by lack of love, because you are the dearest of my children. It is more caused by my lack of means and poverty. And my other children will be made workers [or "artisans"]. But you will be better at finding a position than them." Einarr 
replies: "You have told me this too late, because now everybody has already got the best positions, and it seems bad to me to have the leftovers."

The degree of alienation here might not be as extreme as that found in modern capitalism, but it is a model which any capitalist would recognize: those who do not own the means of production must instead render their labor to others in order to survive. The bor was the "machine" at which this alienated labor was expended, and from which virtually every endogenous commodity in medieval Iceland was produced. When the boer in an Íslendingasaga is presented as a mute, passive backdrop (as is the norm), this socio-economic reality is essentially passed over in silence. When Hlíðarendi and Helgafell are proffered as homotopias, on the other hand, a soothing analgesic for alienation is concocted. The contention of the scenes examined here is that the boer is neither a dull ubiquity nor a place where one serves the needs of an aristocratic master: it can instead be a thing of wonder - a place with which one can have an aesthetic or spiritual connection. The saga author suggests that the exploitative labor-based connection can and should be forgotten. In this sense, the homotopia functions as a form of propaganda.

\section{Conclusion: from bær to industrial estate}

By way of a conclusion, an analogy may be offered between the modes of production in medieval Iceland and the modern West (indeed, large tracts of the rest of the globe too). Just as the boer achieved domination as a means of production in Iceland, in our own time the industrial estate verges on doing the same. By "industrial estate" I include what American English refers to as a "strip mall," and both the varieties that British English refers to as "industrial estate" and "commercial estate" (Bale 1974, 31-32). ${ }^{24}$ As late capitalism hurtles ever further towards the self-destructive dream of an entirely services-based economy (Mandel 1978, 404-407), it is increasingly true that "industrial estates" are not particularly "industrial" in character (cf. Bale 1974, 32-33). Instead, these hives of alienated labor become homogenized brutalist spaces that, like the boer, promise to satisfy every aspect of the production-consumption cycle (or as that cycle is referred to in everyday speech, "life"). Industrial estates, like boeir, are where commodities are both produced and consumed; they are manufacturing centers as well as shops. Just as the boer usually contained the church/ pagan altar and the mead hall, the industrial estate increasingly aims to meet spiritual needs (they often contain churches, for instance). They also attempt to meet some of our other immaterial appetites, offering spaces of hedonistic enjoyment such as pubs, nightclubs, and restaurants.

At first glance it might seem ludicrous to compare the much-vaunted landscapes of rural Iceland with the grey, fiberglass paneling of post-industrial capitalism. One of the reasons such an exercise feels so counter-intuitive is that the industrial estate is today the space of emplacement par excellence. It is a boring place, where a willfully wistful gaze is required to elicit strong emotions. For example, the Slough Trading Estate in Berkshire, UK, is the size of a small town (indeed, it was largely built on top of a small town called Cippenham; Rowley 2006, 141-43), and yet it is very hard to find anything approaching beauty or even distinctiveness in any of its vistas. Iceland today, on the other hand, is generally construed as either a heterotopia or homotopia. The island's heterotopian credentials are presented in the form of its exoticized landscape (and, occasionally, its exoticized people): "the land of fire and ice," or the land of otherworldly, Aryan-to-the-point-of-albinism Icelanders, ${ }^{25}$ 
capable of superhuman feats of coolness and creativity. Alternatively, as Gísli Sigurðsson points out, both tourism and indigenous national romanticism have offered what I would identify as a distinctly homotopian vision of Iceland:

$[\mathrm{T}]$ he Icelanders are officially presented as a united nation, speaking the same language, with a common religious and historical background in the country ... We hear nothing of the recent additions to the cultural scene, with immigrants from other parts of the world who have already changed the eating habits of the natives even though they have not as yet become very visible in politics and public life. What we find served up is, on the one hand, a romantic nationalistic view of the uniqueness of everything Icelandic, and on the other we see a one-sided view of pure nature to be sold expensively to the tourist. $(1996,72)$

Whether posited as a homotopia or heterotopia, nowhere in Iceland is routinely depicted as a space of emplacement in the manner of a modern industrial estate. But for many in the saga-audiences of the Middle Ages, daily experience of the bor would have constituted a Foucauldian space of emplacement: dull, familiar, at times alienating. A Marxian insight into the alienation between the worker and the means of production suggests that glowing feelings towards the landscape were not automatic. Rather, they had to be induced through narrative episodes such as those we saw in Njáls saga and Eyrbyggja saga. Perhaps labor alienation goes some way towards explaining the scarcity of episodes praising the landscape in medieval saga literature. I do not doubt that those who owned boeir, and the landscape features which were often included therein, did have authentically homotopian views of their property (such as Pórólfr "Moster-beard" Mostrarskegg of Helgafell). After all, their land was not just their territory but their source of wealth and power. The creation of homotopias in the sagas, like the "Icelandic Dream" described earlier (Cole 2015a, 40), can therefore be described as just one part of a wider project to make the views of the exploited align with the views of the exploiter. ${ }^{26}$

One last parallel between the boer and the industrial estate is to be found in the industrial estate's emerging (as yet embryonic) transformation from space of emplacement to homotopia. It would be a brave aesthete indeed who argued for the beauty of the Slough Trading Estate in the way that Gunnarr did for Hlíðarendi. Nonetheless, certain media plow a similar furrow in their effort to tranquilize the intrinsic alienation of the industrial estate. The situation-comedy Parks and Recreation (2009-2015) takes place in a fictional city called Pawnee in Indiana (it is in fact filmed in California, a state which offers substantially more clement weather). ${ }^{27}$ Parks and Recreation does not pretend that Pawnee is different from many other settlements in Indiana: an ugly sprawl of industrial estates, beset by terrible social problems. As one local poet from Indiana writes: "Indiana is to me ... [s] trip malls. Miles and miles of strip malls" (Kennedy 2016, 7-8). Yet the comedy presents a distinctly rosy vision of life in the town and the state: great value is put on what is homely and familiar. It does not pretend that Indiana is unusually diverse in any way, either ethnically or geographically. Rather, it projects the message that Indiana's familiarity is in fact the source of its wonder - worth defending and worth sticking with. Exhausted office workers, grayed from a day on the industrial estate, lose their worries in front of the television, thus becoming comrades with the farm laborer on an Icelandic boer, distracted from his or her weary limbs by the vision of Helgafell or Hlíðarendi. 


\section{Notes}

1. On the history of Foucault's heterotopia neologism, which was first used in a radio broadcast in 1966 but not published until 1984, see De Cauter and Dehaene (2008, 13-14).

2. The propensity of the heterotopia to create odd effects in time was left somewhat underexplored by Foucault. It was confined entirely to the "Fourth Principle" of his definition $(1986,26)$, where the examples given were museums and libraries (because time in them is positioned as always accumulating), fairgrounds (because they exist only on the precondition that they will soon cease to exist), and French-Polynesian holiday camps (because they offer an experience of time outside of suburban wage-slavery). It seems to me that the only common denominator between these examples is a generic strangeness of time. The lesser importance which Foucault placed on time for understanding heterotopias is perhaps due to his own skepticism at that point in his career towards the relevance of "time" as a theme: "In any case I believe that the anxiety of our era has to do fundamentally with space, no doubt a great deal more than with time. Time probably appears to us only as one of the various distributive operations that are possible for the elements that are spread out in space" $(1986,23)$. Cf. his cryptic dismissal of those he called "pious descendents [sic] of time" $(1986,22)$. I will return to the issue of time distortion in this essay, though I follow Foucault in my feeling that space is of more gravity than time in the homotopian experience.

3. In Old Norse, see: Sverrir Jakobsson 2010, 68-69, 74-75, 79-80; McDonald Werronen 2013, 141-46. In other medieval literatures, see also: Boyarin 1995; Franklin-Brown 2012, esp. Part 3, "Heterotopias," 215-301.

4. "Everdayness" itself certainly can be emotively charged (see, for instance, Scheer 2012, esp. 209-12). Indeed, a key aspect of homotopias is that they are unremarkable spaces, whose unremarkableness has been so heightened that, paradoxically, they have become remarkable. However, Foucault himself appears to have supposed that the particular category of the "space of emplacement" was emotionally unstimulating.

5. More specifically England and, to a slightly lesser extent Wales. UKIP is yet to make significant inroads in Scotland or Northern Ireland (Seymour 2016, 24-25).

6. The roots of Hastrup's argument can be found in her DPhil $(1979,142-43,304-305)$.

7. See also Thorvaldur Thordarson [Porvaldur Pórðarson] (2010, esp. 288-90). In addition to the sources mentioned by Porvaldur, one might add Bergbúa páttr, and the comparison between the volcanism of Sicily and Iceland found in Konungs skuggsjá. Falk provides further examples (2007). It has been argued that some Old Norse mythological material cryptically acknowledges Iceland's volcanic activity (Nordvig 2015) but this theory is yet to gain widespread acceptance, and is beyond the scope of the present study.

8. The fact that Pórir can "see" this apparition, even though he is by this point blind, suggests either that Pórir is experiencing a vision in his mind's eye, or perhaps that Pórir's blindness or closeness to death allows him to see beings that others cannot.

9. All quotations from sagas are to the editions listed after the quotations, and refer to page numbers in those editions. All translations are my own.

10. The Icelandic tendency to find Irish, Samoyed, or even Giantish princesses in their lineages, even though Samoyeds probably did not have regal culture, and giants do not exist (hopefully no citation is required on that contention) rather calls to mind the modern American tendency to integrate Native American princesses into one's family tree. Amongst other benefits (Logan 1990, 37-39), this fiction confers a degree of aristocracy on an otherwise humble lineage.

11. On the identification of the foreign clerics in Íslendingabók, see: Siân Grønlie (2006, 26-27n77).

12. On the debate surrounding the identification of these ermskir, see Cormack (2007, 231-32). See also Garipzanov $(2011,20-21)$. If the clause in Grágás refers to the sort of missionary activity that Petrus, Abraham and Stephanus undertook, then the missionaries cannot have been of the Latin rite. Whether they were actually Armenian or not has been disputed. Magnús Már Lárusson (1960) suggested that ermskir referred not to Armenia but to Ermland, being Warmia on what is today the northern coast of Poland. Cormack protests that in the ninth century Poland was still largely pagan. Moreover, any Polish missionaries would 
presumably have used Latin liturgy rather than "Armenian or Greek." Armenian clergy do occasionally crop up improbably far west in medieval Europe, e.g. in thirteenth-century St Albans, according to Roger of Wendover and Matthew Paris. Bjørn Bandlien (2014) has drawn attention to a delegation of Armenians to Norway in 1313-1314. Furthermore, Bandlien also illustrates how by the later Middle Ages, Scandinavian views towards Orthodox presence in the north could be quite ambivalent (2016, 338-42).

13. Phelpstead cogently argues that: "[Todorov's] equation of the improbable with the supernatural is nonsense to believers in the supernatural, and at this point Todorov reveals his position's post-Enlightenment historical limitations. It is above all because it takes for granted that the supernatural is improbable that Todorov's approach seems to me ill-suited to the discussion of medieval texts which take for granted the reality of the supernatural. Most of his examples of 'the fantastic' are from the eighteenth to twentieth centuries and it is notable that it is almost exclusively in his discussion of what he calls 'the marvelous' (and regards as improbable) that he refers to pre-modern texts. Given that Todorov's use of the term 'fantastic' is counterintuitive, liable to cause confusion with the everyday sense of the word, and inseparable from a worldview alien to medieval writers, critics would be well advised to look elsewhere for theorizations of 'fantasy' and 'the fantastic' that are better suited for discussion of medieval texts" $(2012,29)$.

14. Cities and towns in Iceland are post-medieval phenomena, mostly dating from the period of the Danish trade monopoly. At the time when most of the sagas were written in the thirteenth century, it might be said that Iceland was developing proto-urban building complexes around major ecclesiastical centres such as Skálholt, but these can scarcely be conceived of as towns or even villages in the conventional sense (Lucas 2015, 108).

15. In the last decade of the post-industrial age new conditions have emerged, at present largely hazily delineated through euphemisms such as "agile labour" or "the disruptive economy." In this situation, the division between "work life" and "personal life" is somewhat eroded: like the caricature of socialism offered by some right-wing commentators, people are encouraged to sell space in their personal cars via internet-based companies that aim to supplant taxis, or to sell space in their own homes via similar enterprises, thereby supplanting hotels. However, no services-based economy has yet relinquished the ideal of compelling people to work in office blocks on industrial estates. Even if it became cheaper to have all office-based work completed at home, one wonders whether that would become the norm. Apologists for capitalism may encourage the myth that their chief interest is to make money, but one suspects that an unacknowledged auxiliary pleasure for capitalists is to exert domination over their fellow human beings.

16. Or perhaps "expected." This translation, which is not preferred in any modern English version, would accord with Allen's view that the saga narrator is disapproving of Gunnarr's supposed flightiness (1971, 149-52).

17. I am grateful to Emily Lethbridge for bringing Edda Waage's work to my attention.

18. Helgafell is often described as a mountain, although its height would make it a humble one by most definitions.

19. I am grateful to Andy Foote for recording the informant's name and location, though I have withheld these details here.

20. For lavatory purposes, Pórólfr designates the island of Dritsker (Turd-skerry).

21. Indeed, I am not the first to appreciate the uniqueness of Helgafell and Hlíðarendi in tandem. Carl Phelpstead notes that: "Helgafell, like Hlíðarendi in Njáls saga, is a part of the landscape that is endowed with meaning in a way that blurs the distinction between human life and the physical environment, between nature and culture" $(2014,9)$.

22. Or recited from memory, if the reader prefers - or perhaps through a mixture of reading and extemporization (Mitchell 1987).

23. For readers unfamiliar with the sagas, it may be illustrative to consider that shepherds in the Íslendingasögur serve a function rather like the similarly nameless "redshirts" from the television series, Star Trek (Gene Roddenberry 1966-1969). They are anonymous, servile, disposable, and normally destined to leave the narrative in a grisly manner not long after 
they have entered it. On the similarly unjust class connotations of these latter figures from modern popular culture, see Booker $(2008,197)$. For a materialist reading of the propensity for draugar to attack and kill shepherds, see Sayers (1996, 258-59).

24. Although Bale's short article is now decades old, as far as I know it remains the most lucid and comprehensive typology of industrial estates published as peer-reviewed scholarship. That industrial estates should have decreased in interest to scholars at the same time as they dominated an increasing share of the world's surface is puzzling. The conundrum may be compared to David Graeber's observation that scholarly interest in "bureaucracy" (in the English-speaking world, at least) appears to have peaked around the point that the triumph of bureaucratic capitalism became complete. "[Bureaucracy] shoots into prominence starting in the fifties and then, after a pinnacle in 1973, begins a slow but inexorable decline. Why? Well, one obvious reason is that we've just become accustomed to it. Bureaucracy has become the water in which we swim" (Graeber 2015, 3-4). It is worth noting that the peak in scholarly interest in bureaucracy appears to be coeval with the peak in interest in industrial estates. A similar effect may be at work with industrial estates: their ubiquity has paradoxically meant that thinkers no longer reflect on their significance. It might be inferred that the two phenomena are related, industrial estates being one of the symptoms of bureaucratic capitalism, but exploring this hypothesis would be the topic for a separate study.

25. The frequency with which the word "pure" is used in connection with Iceland and Icelandic products, coupled with popular conceptions about the blondeness and supposed physical appeal of Icelanders, makes the observer familiar with the historical fascist fixation on Reinheit feel uneasy. To my knowledge, no study has yet been published which explores the manner in which the positive connotations of whiteness are exploited in Icelandic tourist adverts and other Icelandic marketing campaigns intended for an international audience. However, the more general construal of Icelanders as white has been comprehensively analyzed by Kristín Loftsdóttir (e.g. 2011, 2013, 2015).

26. A Marxian reading of the modern situation is also suggested by Gísli Sigurðsson: "Even though the text mentions that Icelanders have to work hard to maintain their high living standards, the pictures do not show people at work, or places where such activity might take place" $(1996,68)$. Note that labor has been obscured from the tourist / National Romantic vision, even though the reality of Iceland's continued existence is dependent upon it. This is entirely consistent with the principle of commodity fetishism (Marx 1936, 63-65; 1961-1967, I. 82-85). The creative labor required to create the tourist industry's fantasy of Iceland is concealed, and the new vision of Iceland, which has been produced, then acquires a desirability of its own.

27. Parks and Recreation (Harris Wittels, 2009-2015). A similarly homotopian vision is offered by the American version of The Office (Greg Daniels 2005-2013). The original British version of the show (Ricky Gervais and Stephen Merchant 2001-2003) is set on the Slough Trading Estate. It depicts life on an industrial estate as a profoundly alienating, emotionally unpleasant experience. The American adaptation is set in Scranton, Pennsylvania, which is a post-industrial town roughly comparable to Slough. However, the American retelling is shot in richer, warmer colours. It depicts the experience of office work on an out-of-town development as ridiculous, but nonetheless charming and even romantic.

\section{Acknowledgments}

An earlier version of this paper was delivered at the conference "Time, Space and Narrative in the Icelandic Sagas" (University of Iceland, March 17-18, 2017). I am particularly grateful for the helpful suggestions of Emily Lethbridge and Torfi Tulinius. My attendance at the conference, "Time, Space \& Narrative in the Icelandic Sagas", where a version of this paper was read, was facilitated by the generous support of the Medieval Academy of America. Kristen Mills provided endlessly patient ears while I explored industrial estates as homotopias, both intellectually and on foot. I am also indebted to the insights of Exemplaria's peer reviewers, and especially Anke Bernau in her capacity as an editor of the journal. Any shortcomings that remain are my own. 


\section{Notes on contributor}

Richard Cole is an Old Norse philologist. He is currently a Leverhulme Early Career Fellow in the Department of Scandinavian Studies at University College London. From August 2018 he will take up the position of Assistant Professor of Medieval European History at Århus Universitet. He has previously held teaching and research positions at Harvard University and the University of Notre Dame.

\section{References}

Allen, Richard F. 1971. Fire and Iron. Critical Approaches to Njáls saga. Pittsburgh: University of Pittsburgh Press.

Ashurst, David. 2000. "Bleikir Akrar - Snares of the Devil? The Significance of the Pale Cornfields in Alexanders saga." Saga-Book 25: 272-291.

Bale, J. R. 1974. “Towards a Definition of the Industrial Estate: A Note on a Neglected Aspect of Urban Geography.” Geography 59 (1): 31-34.

Bandlien, Bjørn. 2016. "Norway, Sweden, and Novgorod: Scandinavian Perceptions of the Russians, Late Twelfth - Early Fourteenth Centuries." In Imagined Communities on the Baltic Rim, from the Eleventh to Fifteenth Centuries, edited by Wojtek Jezierski and Lars Hermanson, 331-352. Amsterdam: Amsterdam University Press.

Bandlien, Bjørn. 2014. “The Armenian Embassy to King Håkon V of Norway." Journal of the Society for Armenian Studies 23: 49-82.

Barraclough, Eleanor Rosamund. 2012. "Naming the Landscape in the Landnám Narratives of the Íslendingasögur and Landnámabók." Saga-Book 36: 79-101.

Barreiro, Santiago. 2015. "Genealogy, Labour and Land. The Settlement of the Mýramenn in Egils saga." Networks and Neighbours 3 (1): 22-44.

Bergsveinn Birgisson. 2013. Den svarte vikingen. Oslo: Spartacus.

Boberg, Inger M. 1966. Motif-Index of Early Icelandic Literature. Bibliotheca Arnamagnæana 27. Copenhagen: Munksgaard.

Booker, M. Keith. 2008. “The Politics of Star Trek." In The Essential Science Fiction Television Reader, edited by J. P. Telotte, 195-208. Lexington: University Press of Kentucky.

Boyarin, Daniel. 1995. "Homotopia: The Feminized Jewish Man and the Lives of Women in Late Antiquity." Differences: A Journal of Feminist Cultural Studies 7 (2): 41-81.

Brandr Jónsson. 1925. Alexanders saga. Edited by Finnur Jónsson. Copenhagen: Gylendalske boghandel.

Brennu-Njáls saga. 1954. Íslenzk fornrit 12. Edited by Einar Ól. Sveinsson. Reykjavík: Hið íslenzka fornritafélag

Clunies Ross, Margaret. 2002. "Realism and the Fantastic in the Old Icelandic Sagas." Scandinavian Studies 74 (4): 443-454.

Cole, Richard. 2015a. "Árna saga biskups / Kafka / Bureaucracy / Desire." Collegium Medievale 28: 37-69.

Cole, Richard. 2015b. “The Jew Who Wasn't There: Studies on Jews and their Absence in Old Norse Literature." PhD Diss., Harvard University.

Cormack, Margaret. 2007. "Irish and Armenian Ecclesiastics in Medieval Iceland." In West over Sea: Studies in Scandinavian Sea-Borne Expansion and Settlement before 1300, edited by Beverly Ballin Smith, Simon Taylor, and Gareth Williams, 227-234. Leiden: Brill.

De Cauter, Lieven, and Michiel Dehaene. 2008. "Introduction' to Michel Foucault, 'Of Other Spaces'. In Heterotopia and the City: Public Space in a Postcivil Society, introduced, translated, and edited by De Cauter and Dehaene, 13-29, at 13-14. London: Routledge.

Einar Ól. Sveinsson. 1954. "Introduction." In Brennu-Njáls saga, edited by Sveinsson, v-cixviii. Reykjavík: Hið íslenzka fornritafélag.

Eyrbyggja saga. Brands páttr ǫrva. Eiríks saga rauða. Grœnlendinga saga. Gronlendinga páttr. 1935. Íslenzk fornrit 4. Edited by Einar Ól. Sveinsson and Matthías Pórðarson. Reykjavík: Hið íslenzka fornritafélag. 
Falk, Oren. 2007. "The Vanishing Volcanoes: Fragments of Fourteenth-Century Icelandic Folklore." Folklore 118 (1): 1-22.

Foote, Peter, and David M. Wilson. 1970. The Viking Achievement: The Society and Culture of Early Medieval Scandinavia. London: Sidgwick and Jackson.

Foote, Peter. 2004. "Bréf til Haralds." In Kreddur: Select Studies in Early Icelandic Law and Literature, edited by A. Finlay, Orri Vèsteinsson, Svanhildur Óskarsdóttir and Sverrir Tómasson, 196-201. Reykjavík: Hið íslenzka bókmenntafélag.

Foote, Peter. 1984. “The Audience and Vogues of the Sagas of Icelanders - Some Talking Points." In Aurvandilstá. Norse Studies, edited by Michael Barnes, Hans Bekker-Nielsen, and Gerd Wolfgang Weber, 47-55. Odense: Odense University Press.

Foucault, Michel. 1986. "Of Other Spaces [Des espaces autre, 1967]." Translated by Jay Miskowiec. Diacritics 16 (1): 22-27.

Franklin-Brown, Mary. 2012. Reading the World: Encyclopedic Writing in the Scholastic Age. Chicago: University of Chicago Press.

Garipzanov, Ildar. 2011. "Early Christian Scandinavia and the Problem of Eastern Influences." In Early Christianity on the Way from the Varangians to the Greeks, edited by Ildar Garipzanov and Oleksiy Tolochko, 17-32. Kiev: Ruthenica.

Gísli Sigurðsson. 1996. “Icelandic National Identity From Romanticism to Tourism.” In Making Europe in Nordic Contexts, edited by Pertti J. Anttonen, 41-75. Turku: Nordic Institute for Folklore.

Graeber, David. 2015. The Utopia of Rules: On Technology, Stupidity, and the Secret Joys of Bureaucracy. London: Melville House.

Grágás, Skálholtsbók m.m. Genoptrykt efter Vilhjálmur Finsens udgave 1883. 1974. Edited by Vilhjálmur Finsen. Odense: Odense Universitetsforlag.

Grønlie, Siân. 2006. "Notes to the Book of the Icelanders." In Íslendingabók: Kristni saga. The Book of the Icelanders: The Story of the Conversion, translated by Grønlie, vii-xlvi. London: Viking Society for Northern Research.

Gunnar Karlsson. 1975. “Atvinnuhættir.” In Saga Íslands. 2 vols., edited by Sigurður Líndal, 5-28. Reykjavík: Hið íslenzka bókmenntafélag.

Haki Antonsson. 2012. "Salvation and Early Saga Writing in Iceland: Aspects of the Works of the Pingeyrar Monks and their Associates." Viking and Medieval Scandinavia 8: 71-140.

Hastrup, Kirsten. 1979. "Cultural Classification and History: With Special Reference to Mediaeval Iceland.” DPhil., University of Oxford.

Hastrup, Kirsten. 1981. "Cosmology and Society in Medieval Iceland: A Social Anthropological Perspective on World-View." Ethnologia Scandinavica 11: 63-78.

Hastrup, Kirsten. 1993. “Cosmography.” In Medieval Scandinavia: An Encyclopedia, edited by Phillip Pulsiano and Kirsten Wolf, 108-109. New York: Garland.

Henderson, Ebenezer. 1819. Iceland; or the Journal of a Residence in that Island, during the years 1814 and 1815. 2nd ed. Edinburgh: Waugh and Innes.

Hermann Pálsson, and Paul Edwards. 1972. “Translators' Introduction.” In The Book of Settlements: Landnámabók, translated by Pálsson and Edwards, 1-11. Winnipeg: University of Manitoba Press. Hermann Pálsson. 1996. Keltar á Íslandi. Reykjavík: Háskólaútgáfan.

Hrafnkels saga. Austfirð̇inga sǫgur. Porsteins saga hvíta. Vápnfirðinga saga. Porsteins páttr Stangarhǫggs. Qlkofra páttr. Hrafnkels saga Freysgoða. Droplaugarsona saga. Brandkrossa páttr. Gunnars páttr Piðrandabana. Fljótsdcela saga. Porsteins saga Síðu-Hallssonar. Draumr Porsteins Síðu-Hallssonar. Porsteins páttr Austfirðings. Porsteins páttr sǫufróða. Gull-Ásu-Pórðar páttr. 1950. Íslenzk fornrit 11. Edited by Jón Jóhannesson. Reykjavík: Hið íslenzka fornritafélag.

Íslendingabók. 1968. In Íslendingabók. Landnámabók, edited by Jakob Benediktsson, 3-28. Íslenzk fornrit 1. Reyjavík: Hið íslenzka fornritafélag.

Jón Jóhannesson. 1974. A History of the Old Icelandic Commonwealth: Íslendinga saga. Translated by Haraldur Bessason. Winnipeg: University of Manitoba Press.

Kennedy, Deborah. 2016. "Indiana Is ....” In Undeniably Indiana: Hoosiers Tell the Story of Their Wacky and Wonderful State, 5-7. Bloomington: Indiana University Press.

Kristín Loftsdóttir. 2011. "Negotiating White Icelandic Identity: Multiculturalism and Colonial Identity Formations." Social Identities 17 (1): 11-25. 
Kristín Loftsdóttir. 2013. "Republishing 'The Ten Little Negros': Exploring Nationalism and 'Whiteness' in Iceland." Ethnicities 13 (3): 295-315.

Kristín Loftsdóttir. 2015. "Within a 'White’ Affective Space: Racialization in Iceland and Development Discourses." Social Identities 20 (6): 452-470.

Landnámabók. 1968. In Íslendingabók. Landnámabók, edited by Jakob Benediktsson, 31-397. Íslenzk fornrit 1. Reyjavík: Hið íslenzka fornritafélag.

Laxdoela saga. Halldórs poettir Snorrasonar. Stúfs páttr. 1934. Íslenzk fornrit 5. Edited by Einar Ól. Sveinsson. Reykjavík: Hið íslenzka fornritafélag.

Lethbridge, Emily. 2016. “The Icelandic Sagas and Saga Landscapes: Writing, Reading and Retelling Íslendingasögur Narratives.” Gripla 27: 51-92.

Liddell, Henry George, and Robert Scott. 1996. A Greek-English Lexicon. Oxford: The Clarendon Press.

Logan, Michael H. 1990. “My Great Grandma was a Cherokee Indian Princess': Ethnic Forgery or Darwinian Reality." Tennessee Anthropologist 15 (1): 34-43.

Lucas, Gavin. 2015. “Building Lives." In Elements of Architecture: Assembling Archaeology, Atmosphere and the Performance of Building Spaces, edited by Mikkel Bille and Tim Flohr Sørensen, 105-120. London: Routledge.

Lönnroth, Lars. 1976. Njáls saga: A Critical Introduction. Berkeley: University of California Press. Magnús Már Lárusson. 1960. “On the So-Called ‘Armenian’ Bishops.” Studia Islandica 18: 23-38. Mandel, Ernest. 1978. Late Capitalism. Translated by Joris De Bres. London: Verso.

Marx, Karl. 1936. The Poverty of Philosophy. Moscow: Foreign Languages Publishing House.

Marx, Karl. 1961-1967. Capital. 3 vols. Translated by Samuel Moore and Edward Aveling, edited by Frederick Engels. Moscow: Foreign Languages Publishing House.

Marx, Karl. 1975. Early Writings. Translated by Rodney Livingstone and Gregor Benton. London: Penguin Books.

Marx, Karl. 1976. Wage-Labour and Capital and Value, Price and Profit. Edited and translated by Frederick Engels. New York: International Publishers.

Mayburd, Miriam. 2014. “The Hills Have Eyes: Post-Mortem Mountain Dwelling and the (Super) Natural Landscape in the Íslendingasögur.” Viking and Medieval Scandinavia 10: 129-154.

Mc Donald Werronen, Sheryl Elizabeth. 2013. “Transforming Popular Romance on the Edge of the World: Nítíða saga in Late Medieval and Early Modern Iceland." PhD Diss., University of Leeds.

Mitchell, Stephen A. 1987. “The Sagaman and Oral Literature: The Icelandic Traditions of Hjörleifr inn kvensami and Geirmundr heljarskinn." In Comparative Research on Oral Traditions: A Memorial for Milman Parry, edited by John Miles Foley, 395-423. Columbus: Slavica Publishers.

Mitchell, Stephen A. 1991. Heroic Sagas and Ballads. Ithaca: Cornell University Press.

Nagle, John. 2009. Multiculturalism's Double Bind: Creating Inclusivity, Cosmopolitanism and Difference. Farnham: Ashgate.

Nordvig, Mathias Valentin. 2015. “What Happens when 'Hider' and 'Screamer' Go Sailing with 'Noisy'? Geomythological Traces in Old Icelandic Mythology." In Past Vulnerability: Volcanic Eruptions and Human Vulnerability in Traditional Societies Past and Present, edited by Felix Riede, 75-88. Aarhus: Aarhus University Press.

O'Connor, Ralph. 2002. "Introduction." In Icelandic Histories and Romances, translated by Ralph O’Connor, 9-81. Stroud: Tempus.

Overing, Gillian R., and Marijane Osborn. 1994. Landscape of Desire: Partial Stories of the Medieval Scandinavian World. Minneapolis: University of Minnesota Press.

Phelpstead, Carl. 2012. "Fantasy and History: The Limits of Plausibility in Oddr Snorrason's Óláfs saga Tryggvasonar.” Saga-Book 36: 27-42.

Phelpstead, Carl. 2014. "Ecocriticism and Eyrbyggja saga." Leeds Studies in English 45: 1-18.

Rowley, Trevor. 2006. The English Landscape in the Twentieth Century. London: Hambledon Continuum.

Sayers, William. 1994. "Management of the Celtic Fact in Landnámabók." Scandinavian Studies 66 (2): 129-153.

Sayers, William. 1996. “The Alien and Alienated as Unquiet Dead in the Sagas of the Icelanders." In Monster Theory: Reading Culture, edited by Jeffrey Jerome Cohen, 242-263. Minneapolis: University of Minnesota Press. 
Schach, Paul. 1972. "Some Observations on the Helgafell Episode in Eyrbyggja saga and Gísla saga." In Saga og språk: Studies in Language and Literature, edited by John M. Weinstock, 113-145. Austin: Pemberton Press.

Scheer, Monique. 2012. "Are Emotions a Kind of Practice (and Is That What Makes Them Have a History)? A Bourdieuian Approach to Understanding Emotion." History and Theory 51: 193-220.

Seymour, Richard. 2016. "UKIP and the Crisis of Britain." Socialist Register 52: 24-50.

Ström, Folke. 1958. "Döden och de döda." In Kulturhistorisk leksikon for nordisk middelalder. 3 vols., edited by Allan Karker, 432-438. Copenhagen: Rosenkilde and Bagger.

Sundqvist, Olof. 2015. An Arena for Higher Powers: Ceremonial Buildings and Religious Strategies for Rulership in Late Iron Age Scandinavia. Leiden: Brill.

Sverrir Jakobsson. 2010. "State Formation and Pre-modern Identities in the North: A Synchronic Perspective from the Early 14th Century." Arkiv för nordisk filologi 124: 67-82.

Thorvaldur Thordarson [Porvaldur Pórðarson]. 2010. "Perception of Volcanic Eruptions in Iceland." In Landscapes and Societies, edited by I. P. Martini and W. Chesworth, 285-296. New York: Springer.

Todorov, Tzvetan. 1975. The Fantastic: A Structural Approach to a Literary Genre. Translated by Richard Howard. Ithaca: Cornell University Press.

Torfi Tulinius. 2011. "Grettir and Bjartur: Realism and the Supernatural in Medieval and Modern Icelandic Literature." Scandinavian-Canadian Studies 20: 14-25.

Torfi Tulinius. 2006. "Is Snorri goði an Icelandic Hamlet? On Dead Fathers and Problematic Chieftainship in Eyrbyggja saga." In The Fantastic in Old Norse/Icelandic Literature: Preprint Papers of the 13th International Saga Conference, Durham and York 6th-12th August 2006. 2 vols., edited by John S. McKinnell, David Ashurst, and Donata Kick, 961-970. Durham: Centre for Medieval and Renaissance Studies.

Vésteinn Ólason. 2003. "Notes." In Gisli Sursson's Saga and The Saga of the People of Eyri, translated by Judy Quinn and Martin S. Regal, 201-229. London: Penguin Books.

Waage, Edda R. H. 2012. "Landscape in the Sagas of Icelanders: The Concepts of Land and Landsleg." Norsk Geografisk Tidsskrift 66 (4): 177-192.

Wanner, Kevin J. 2009. "Purity and Danger in Earliest Iceland: Excrement, Blood, Sacred Space, and Society in Eyrbyggja saga." Viking and Medieval Scandinavia 5: 213-250.

Wawn, Andrew. 1992. “The Spirit of 1892: Sagas, Saga-Steads and Victorian Philology." Saga-Book 23: $213-252$. 